\title{
Innovations as borders of stages of coal industry historical development
}

\author{
Elena Sigareva ${ }^{1}$, Sergey Popov $^{1}$, Sergey Baturin ${ }^{1, *}$, Nadezhda Sidorova ${ }^{1}$, Margarita \\ Borisova $^{1}$ \\ ${ }^{1}$ Kemerovo institute (branch) of Plekhanov Russian University of Economics, Department of \\ Humanities, 39 Kuznetsky av., Kemerovo, Russia
}

\begin{abstract}
The article deals with the historical development of mineral deposits exploitation which has very old history. Several thousands of years hid from us where and when people first began to extract minerals from the interior of the earth. With the development of human society the extraction of minerals has been increasing steadily. Nowadays the growth of extraction is accompanied by the deterioration of mining and geological conditions of mining operations, reducing mineralization in the deposit. As a result of intensive development mineral reserves located near the soil surface have changed significantly. Modern open-casts, open pits, and mines are highly productive and automated production complexes, including very extensive and diverse mining, various industrial buildings and facilities, the system of energy-mechanical equipment, automation and control with the use of microcomputer equipment. The paper describes a number of stages which modern mining in its development had passed and at which innovative breakthrough radically changed the place of the mineral sector in the society, and made the work of miners safer and more productive. For the systemization of the historical development of coal industry it is important to identify those technological breakthroughs that radically changed the technological and technical conditions of mining.
\end{abstract}

\section{Introduction}

Solid minerals are mined from the interior of the earth in two main ways - opencast and underground. Moreover, the level of open-pit mining in the world is about $80 \%$ [1]. The innovative development of mining is largely due to the open pit mining extension $[2,3]$. It is explained by low, compared with the underground method, cost price of 1 ton of extracted raw material. The main technological conditions of innovative development of mining industry are favorable mining and technological conditions: relatively shallow bedding, large capacity of mineral resources, and the ability to use highly productive stripping, mining and transport equipment, powerful machineries (excavators, drilling machines, etc.), dump trucks [4-5].

\footnotetext{
* Corresponding author: language1994@mail.ru
} 


\section{Material and Methods}

The origin of mining science appeared in ancient times. Even Pliny the Elder left the work in mining, where he gave some facts related to the extraction of ore and building materials. In the same way another ancient encyclopedist Vitruvius described the origin of mining. In his book "On Architecture" he wrote about the terrible evaporation of noxious gases (carbon dioxide) from the bottom of mine draw-well and how the miners burned them out with the help of torch. He also wrote about the discovery of underground rivers.

The first innovations that determined the very appearance of mining science became mechanisms which facilitated the work of people. The history of mechanics begins with the works of Greek and Egyptian scientists. In remained up to the present day papyrus books there are the results of the simplest tasks of statics, which put the ground for the theory of equilibrium. Some guesses and provisions made by the outstanding philosopher Aristotle (384-322 BC.) did not lose their significance today. That was Aristotle who introduced the concept of "mechanics" that defined the area of human knowledge within which we study the motion of material bodies being in nature or appeared as a result of human activity.

Among the famous scholars of ancientry a special place is occupied by Arhimed (287212 BC) who used the first mathematical method of solving many theoretical and practical problems. He developed the foundations of equilibrium doctrine, the principles of statics of solid bodies, hydrostatic, and made a large number of inventions.

As a result of the birth of ancient mechanics the first mines received lifting machines, grinders, and the first type of cutting and chipping tools.

Further innovative development of mining operations is marked by the creation of a number of simple lifting, ventilation, dewatering machines. Their thorough description is given in the works of Georg Agricola (1494 - 1555), the mining science founder.

In times of Agricola mining development gained a new impetus in connection with the first attempts to systematize the production of raw material technology. In particular, the principles of opening the deposits, depending on the shape and bedding of ore body groves, vertical and inclined bores were defined. The bores usually had a rectangular cross section with dimensions of 3 per $4.5 \mathrm{~m}$. Their depth sometimes reached up to $145 \mathrm{~m}$. Inclined working were widely spread, as well as horizontal one, conducted on the mineral vein.

The first mention of the systematic coal mining in Europe refers to $1100-1200$. The destruction of forests in densely populated areas was a background for the development of coal deposits. The earliest systems of coal development were chambered, applied on the flat seams of average power.

In XVII-XVIII centuries rails (initially in the form of wooden beams with a metal plate, and then from the angle profile of iron) were used in transporting.

In connection with the development of coal industry ventilation of mine working was improved. Ventilation with air heating was widely used.

Since the XVIII century the Industrial Revolution gave rise to the innovative activities: steam engines appeared; coal was widely used as an energy source; steel became the main structural material; the railways were being built. The XX century was characterized by more significant qualitative changes in industry, as a result of which coal went to the first place among energy products.

The first steam turbines and internal combustion engines, electrical machines appeared. Motor drive made it possible to solve the problem of mechanized delivery of minerals. Underground equipment was provided with electric motors. Their use brought great changes in the organization of drainage and ventilation.

Started at that period scientific and technological revolution continues today, changing the face of mining enterprises. 
The coal industry is one of the branches of modern fuel and energy sector; it has been existing for not one century. However, the study of its history is relatively recent. The main flow of works falls on the second half of the 40ies of the XX century. It was the World War II which revealed a particularly significance of the fuel and energy complex, not only for the development but also for the existing of nations, their security and independence. During this period scientists gave a general description of periods in coal industry development, its current situation and future prospects. Later, in 1970-80ies the scholars started to consider the process of institutional evolution of industry, the social-andeconomic conditions of miners. Current studies include the possibility of coal use in various industries, the historic "competition" of oil and coal in modernizing economy of industrialized countries, technological development, and others. It is obvious that during the existence of the industry it has been going through various stages. Labor conditions, the cost structure, the profitability of coal production and its use were changing. Modern needs in technical-technological development of domestic production require paying special attention to the historical experience of innovative development of the coal industry.

\section{Results and Discussion}

As a result of the retrospective analysis of the mining industry genesis we identified the following stages in its development.

The first stage is associated with the formation of the industrial demand for coal, which promoted the innovative development of industry. In fact, until the early 18 th century coal mining had "pre-industrial development". It was associated with the use of it as a fuel in ancient China and Greece, as well as throughout the Middle Ages. For example, in Europe in 1095 for the first time the fact of using coal for heating in France was documented. In 1537 , in Zwickau (Saxony) the first association for coal production was founded. At the end of the pre-industrial period a new direction in using the product was formed. In $1589 \mathrm{~J}$. Peterson received the coke from coal, used later in the melting, and in 1709 A. Derby for the first time smelted iron using coke produced from mineral coal instead of char coal.

The second stage (XVIII c.) or an early industrial development stage is characterized by the appearance of the first mechanical devices to facilitate the manual labor. However, their level made low productivity growth. At that time, the coal industry got modern features during the destruction of medieval crafts, changing craftsman-miners into the hired workers and emergence of mining and metallurgical manufactures. In 1740 the first industrial development of coal began in the United States, and in 1761 the patent for a mechanical device to undercut the coal seam was granted. In addition, the second stage is characterized by the first changes in the technology of coal mining process; the basic operations of the coal enrichment appeared.

The third stage marked the initial technological development of coal industry. The industrial breakthrough of the late XVIII - early XIX centuries served as an incentive for increasing mineral extraction as an energy basis in industrial production of the developed countries: England, Germany, France. The demand for machines caused the development of metallurgical industry. The demand for iron ore and coal for coke production and use of fossil fuel increased. The Industrial Revolution played an important role in expanding the scope of coal usage: during the first half of the XIX century coal began to be used as fuel for steam boilers for water and rail transport.

In the XIX century, in relation to the development of mining, innovations were developed primarily to improve productivity in coal industry. In 1835 in the United States the main machine patent was issued for the open development method - single-bucket steam excavator on rail travel, and in 1852 in England disk cutting machine for coal mines was patented. In 1860 French engineer M. Cuvre invented the multi-bucket excavator, and 
in 1864 in the UK the first chain cutting machine was produced; in 1876 in Germany, a hydraulic rotary drilling machine was invented. In 1880 coal was for the first time used to generate electricity, and in 1884 the electric drilling machine was invented.

At the same time in the United States the first in the world dragline for open pit mining was made. In 1902-1906 in the coal mines of England drag bar and extensible belt conveyers began to appear, and in Germany - shaking conveyors to transport mined coal. However, the machinery in the coal industry appears not only to increase productivity, but also to improve the safety of work. In 1815 H. Davy invented the miner's lamp, which led to the reduction of the explosion risk in mines. Due to the use of fine-granular metal grid, which was placed on an oil lamp the work in mine became more safety.

The fourth stage in the development of coal industry is connected with further development of equipment and production technology. But in this period the attention is given not so such to the equipment (wide-web winning by combined machine with individual metal single prop support, 1945-1965) as to the technology. In the industry to reduce the costs the drilling-and-blasting technique with mechanical coal cutting started to be used widely (1930-1940). At the fourth stage of development of coal industry there was the slowdown in productivity growth and improving the production technologies. In 1950ies the technological development of coal industry continued due to the introduction of narrow-web winning by combined machine and skimmers with individual metal single prop support (1955-1970), and the use of complex-mechanized winning by combined machines and skimmers with hydroficated metal single prop support (1961-1980). This stage is characterized by the active displacement of coal from the fuel and energy complex of the industrialized countries by hydrocarbon fuel - cheaper and more multifunctional type of energy.

The fifth stage, which continues up to now, is associated with re-orientation of innovative activity of scientists from extraction stage to other stages of production process (enrichment, environmental safety, the improvement of coal quality characteristics). The priority areas of coal industry at this stage and up to now is to improve the quality and other consumer properties of coal products with new coal enrichment technologies and its deep processing. Technologies of complex processing for getting domestic termo-brickets from brown coal and coal-rock sludge and screenings are promising. Coal-wastes would be burned in a mini steam-electric plant with technology of burning sludge in the circulating boiling layer, placed near mine, open pit, or ore-processing plant. This will reduce emissions of sulfur dioxide, nitrogen oxides, aromatic hydrocarbons and benzopyrene.

The International Energy Agency made three forecasts of coal industry for the next few decades:

1. The world coal consumption will continue to grow and by 2035 will increase by $70 \%$.

2. The demand for coal will fall sharply by 2020 because of the strict environmental requirements of the majority of developed countries.

3. The peak consumption of coal will be in 2020 , and further the demand for this resource will steadily decline.

The latest forecast is the most likely to be. Environmental problems connected with coal mining and falling of gas prices for the majority of countries are sufficient arguments in favor of reducing the consumption of this resource [6,7]. The projected growth in consumption in India and some other Asian countries cannot compensate the decline in demand for coal in Europe, China, Russia and the United States.

Compared with oil and gas, coal is cheap raw material, so most mining companies operate with low margins. The only way out for the companies in this industry is the development of innovative technologies for deep coal processing, which allow significantly increase the profit. 
Tough environmental standards in some cases may be not obstacles, but incentives for the development of coal mining [8,9]. The Kyoto Protocol established quotas on emissions of methane - gas that is present in mines. Utilization of methane has become profitable for many enterprises which decrease emissions in the mines, and then sell their quotas to other companies. Profit from these projects makes tens millions of dollars [10].

Another promising technology is coal gasification, which is actively developed in China. It is planned that by 2020 the country will produce 50 billion tons of synthesis-gas, which is equivalent to 25 billion tons of natural gas, taking into account the difference in calorific power [11]. Moreover, according to official figures the cost price of million caloricity units of synthesis-gas is almost twice lower than the cost of one million caloricity units of natural fuel imported into the country.

Coal can even replace oil: currently in South Africa several plants that produce motor fuel from coal are operating. These technologies have been used for a long time. South Africa started to develop the production of synthetical fuel as early as the 1980 s, when Western sanctions prevented petroleum imports.

\section{Conclusions}

Summing up it should be mentioned that the strategy of development the coal industry cannot ignore the identification of stages in its innovative development. First of all, they concern not the equipment but technologies of coal mining, enrichment, ecological safety, improving coal quality characteristics. These factors should be the ground of competitiveness management in modern market conditions of the coal enterprise.

\section{References}

1. M. A. Tyulenev, T. N. Gvozdkova, S. A. Zhironkin, E.A. Garina, Geotech. Geol. Eng., 35:1, 203 (2017)

2. M. Tyulenev, S. Zhironkin, K. Kolotov, E. Garina, Poll. Res., 35:2, 221 (2016)

3. M.A. Tyulenev, S.A. Zhironkin, E.A. Garina, Int. J. of Mining and Mineral Engineering, 7:4, 363-370 (2016)

4. T. Gvozdkova, M. Tyulenev, S. Zhironkin, V. Trifonov, Yu. Osipov, IOP Conf. Ser.: Earth Environ. Sci., 50, 012010 (2017)

5. M. Tyulenev, E. Garina, A. Khoreshok, O. Litvin, Y. Litvin, E .Maliukhina, IOP Conf. Ser.: Earth Environ. Sci., 50, 012035 (2017)

6. M. A. Tyulenev, Y. V. Lesin, Mining 2014: Taishan academic forum-Project on mine disaster prevention and control, 441 (Atlantis Press, Paris, 2014)

7. Yu. V. Lesin, Luk'yanova S. Yu., M. A.Tyulenev, J. Min. Sc., 46:1, 78 (2010)

8. A. A. Khoreshok, S. A. Zhironkin, M. A. Tyulenev, G. A. Barysheva, V. Yu. Blumenstein, M. C. Hellmer, S. V. Potyagailov, IOP Conf. Ser.: Mater. Sci. Eng., 142, 012122 (2016)

9. S. A. Zhironkin, A. A. Khoreshok, M. A. Tyulenev, G. A. Barysheva, M. C. Hellmer, IOP Conf. Ser.: Mater. Sci. Eng., 142, 012127 (2016)

10. S. A. Zhironkin, K. A. Kolotov, A. E. Genin, F. V. Agafonov, S. A. Kovalevsky, IOP Conf. Ser.: Earth Environ. Sci., 50, 012011 (2017)

11. V. Trifonov, O. Loyko, D. Nesteruk, S. Zhironkin, E. Strekovtsova, AIP Conf. Proceed., 1800, 050009 (2017) 